\title{
MOTIVASI DAN KEWIRAUSAHAAN UNTUK MENINGKATKAN PEREKONOMIAN IBU RUMAH TANGGA DI KELURAHAN SENDANG SARI KEC. KISARAN BARAT
}

\author{
Hommy D. E. Sinaga*, Chitra Latiffani \\ Program Studi Sistem Informasi, STMIK Royal Kisaran \\ E-mail: *omisinaga@ royal.ac.id
}

\begin{abstract}
Housewives can be entrepreneurs by conducting productive innovation activities at home, so they do not need to leave their home but they also can help increase family income through entrepreneurship. The initial motivation that arises in a housewife for entrepreneurship is for family financial reasons. In addition there is also another motivation, having a particular hobby so that the products from that activities can be sell. Another motivation reason is to do their own career and to get their achievement. From the training conducted for 2 (two) days at Kelurahan Sendang Sari, Kecamatan Kisaran Barat he results were obtained that it is believed that participants gained knowledge, full understanding of entrepreneurship, motivation to do entrepreneurship, the development of the creative economy, strengthening encouragement for housewives to make decision to do entrepreneurship in creative industries.
\end{abstract}

Keywords: Motivation, Entrepreneurship, Housewives

\begin{abstract}
Abstrak: Para ibu rumah tangga dapat menjadi entrepreneur (wirausaha) dengan melakukan kegiatan-kegiatan inovasi yang produktif dari rumah, sehingga mereka tidak perlu meninggalkan rumah tetapi juga dapat membantu menambah pendapatan keluarga melalui wirausaha. Motivasi awal yang muincul pada diri seorang ibu rumah tangga untuk berwirausaha adalah karena alasan keuangan keluarga. Selain itu ada juga motivasi lain yaitu memiliki hobby tertentu sehingga produk yang muncul dari kegiatan menyalurkan hobby yang dapat dijual. Motivasi lainnya adalah keinginan untuk memiliki karir sendiri dan untuk berprestasi. Dari hasil pelatihan yang dilakukan selama 2 (dua) hari di Kelurahan Sendang Sari, Kecamatan Kisaran Barat diperoleh hasil bahwa diyakini peserta mendapatkan pengetahuan, pemahaman tentang apa itu wirausaha, motivasi untuk berwirausaha, perkembangan ekonomi kreatif dan penguatan dorongan bagi para ibu untuk mengambil keputusan melakukan wirausaha pada bidang industri kreatif.
\end{abstract}

Kata Kunci: Motivasi, Wirausaha, Ibu Rumah Tangga 
Jurdimas (Jurnal Pengabdian Kepada Masyarakat) Royal

Vol. 2 No. 1, Jan 2019, hlm. 43 - 48

DOI: https://doi.org/10.33330/jurdimas.v2i1.319

ISSN 2614-7912 (Print)

ISSN 2622-3813 (Online)

Available online at https://jurnal.stmikroyal.ac.id/index.php/jurdimas

\section{PENDAHULUAN}

Selama ini orang selalu mengganggap pekerjaan ibu rumah tangga adalah pekerjaan yang mudah. Tidak ada hal berarti yang harus dikerjakan, hanya menunggui anak main dan suami pulang kerja. Ibu rumah tangga juga dianggap punya terlalu banyak waktu luang yang akhirnya hanya digunakan untuk bergosip dengan tetangga sebelah. Padahal menjadi ibu rumah tangga tidak semudah kelihatannya. Mengatur manajemen rumah, mengasuh anak, menyiapkan segala kebutuhan keluarga dan hal-hal penting lainnya yang ilmunya tidak akan didapatkan dari bangku sekolah pun menjadi pekerjaan ibu rumah tangga.

Menjadi seorang ibu rumah tangga tentunya memiliki tanggung jawab penuh terhadap rumah, suami dan anak-anak. Tidak banyak rutinitas selain membersihkan rumah, mengurus suami dan anak-anak yang biasanya di lakukan para ibu rumah tangga dan hal ini terkadang menimbulkan kebosanan. Nah kebosanan inilah yang dapat dimanfaatkan oleh para ibu rumah tangga untuk dapat membantu perekonomian keluarga serta menghasilkan peluang usaha.

Ibu rumah tangga sebagai pendamping suami dapat secara bersamasama membantu para suami menambah pendapatan rumah tangga dengan melakukan kegiatan wirausaha yang produktif tanpa perlu meninggalkan rumah. Salah satu kegiatan produktif yang dapat dilakukan oleh para ibu rumah tangga adalah kegiatan pengembangan ketrampilan (lifeskills) berbasis industri kreatif.

\section{Wirausaha}

Kewirausahaan menurut Kamus Besar Bahasa Indonesia, pengertian wirausaha sama dengan wiraswasta, yaitu orang yang pandai atau berbakat mengenali produk baru, menentukan cara produksi baru, menyusun operasi untuk pengadaan produk baru, memasarkannya serta mengatur pemodalan operasinya. Ada banyak pengertian yang berbeda-beda tentang defenisi wirausaha menurut para ahli, tetapi intinya adalah kemmapuan untuk menghasilkan sesuatu yang baru dan berbeda dengan mengelola sumber daya yang dimiliki secara efektif dan efisien dengan menanggung risiko dan membuatnya menjadi berhasil mendapatkan keuntungan.

Di dalam pembangunan ekonomi, wirausaha juga merupakan pelaku utama dalam pembangunan ekonomi dimana kegiatan wirausaha ini mampu melakukan inovasi-inovasi untuk perbaikan produksi yang dapat meningkatkan gairah perputaran ekonomi.

Para ibu rumah tangga dapat menjadi entrepreneur (wirausaha) dengan melakukan kegiatan-kegiatan inovasi yang produktif dari rumah, sehingga mereka tidak perlu meninggalkan rumah tetapi juga dapat membantu menambah pendapatan keluarga melalui wirausaha.

Terdapat beberapa peluang usaha untuk ibu rumah tangga yang bisa dikerjakan dirumah pada waktu luang, yaitu:

1. Usaha Kerajinan Tangan.

Kerajinan tangan adalah suatu karya dimana kita membuat karya tersebut menjadi sebuah benda bernilai ekonomis, sebuah benda yang berharga yang sebelumnya tidak bernilai apa-apa. Usaha kerajinan tangan masih menjadi sebuah peluang usaha yang menyimpan potensi yang sangat besar untuk dikembangkan menjadi sebuah bisnis di Negara kita karena sumber daya alamnya yang cukup mendukung. Conrtoh usaha kerajinan tangan adalah: 
Available online at https://jurnal.stmikroyal.ac.id/index.php/jurdimas

a. Usaha kerajinan tangan bros hijab

b. Usaha kerajinan lampu tidur hias dari benang dan balon

c. Usaha kerajinan vas bunga dari botol plastik bekas

d. Usaha kerajinan bantal mobil unik

e. Usaha kerajinan gantungan kunci dari kain flanel

f. Usaha kerajinan boneka

g. Usaha kerajinan dari tempurung kelapa

h. Usaha kerajinan tangan dari sampah plastik

i. Usaha kerajinan tangan decoupage

2. Usaha Rumahan di Bidang Kuliner. Bidang kuliner adalah hasil olahan yang berupa masakan. Masakan tersebut berupa lauk pauk, makanan (penganan) dan minuman. Usaha rumahan di bidang kuliner juga masih menjadi sebuah peluang usaha yang menyimpan potensi yang sangat besar untuk dikembangkan menjadi sebuah bisnis karena setiap daerah memiliki tradisi kuliner yang berbeda-beda. Contoh usaha rumahan di bidang kuliner adalah:

a. Usaha pembuatan telur asin

b. Usaha minuman es buah

c. Usaha minuman jus buah segar

d. Usaha minuman susu kedelai

e. Usaha aneka gorengan

f. Usaha layanan katering

g. Usaha pembuatan bumbu pecal

h. Usaha kue kering

i. Usaha pembuatan tahu bakso

3. Usaha Rumahan di Bidang Perkebunan dan Peternakan.

Perkebunan adalah segala kegiatan yang menguasahakan tanaman tertentu pada tanah dan/atau media tumbuh lainnya dalam ekosistem yang sesuai, sedangkan peternakan adalah kegiatan mengembang biakkan dan membudidayakan hewan ternak untuk mendapatkan manfaat dan hasil dari kegiatan tersebut. Contoh usaha rumahan di bidang perkebunan dan peternakan adalah:

a. Usaha budidaya jamur tiram

b. Usaha budidaya jahe merah

c. Usaha budidaya lele kolam terpal

d. Usaha kangkung organic

e. Usaha budidya burung lovebird

f. Usaha budidaya lobster air tawar

g. Usaha budidaya cabe rawit

h. Usaha budidaya burung puyuh

4. Usaha Rumahan di Bidang Jasa

Jasa adalah setiap tindakan atau unjuk kerja yang ditawaarkan oleh salah satu pihak ke pihak lain yang produksinya bisa terkait dan bias juga tidak terikat pada suatu produk fisik. Usaha di bidang jasa merupakan sebuah bisnis yang menggunakan tenaga, ilmu dan juga keahlian dalam bidang tertentu. Dimana anda akan dibayar sesuai dengan jasa yang telah diberikan, usaha ini telah mengalami peningkatan yang signifikan disbanding tahun sebelunya. Contoh usaha rumahan di bidang jasa adalah:
a. Usaha Warnet
b. Usaha pangkas rambut
c. Usaha bimbingan belajar
d. Usaha jahitan
e. Usaha penitipan anak
f. Usaha penitipan hewan peliharaan
g. Usaha pembayaran tagihan online
h. Usaha cuci motor
i. Usaha laundry

Peluang usaha diatas adalah beberapa contoh peluang bisnis yang bisa di lakukan dan dimanfaatkan oleh ibu 
Jurdimas (Jurnal Pengabdian Kepada Masyarakat) Royal

Vol. 2 No. 1, Jan 2019, hlm. 43 - 48

DOI: https://doi.org/10.33330/jurdimas.v2i1.319

ISSN 2614-7912 (Print)

ISSN 2622-3813 (Online)

Available online at https://jurnal.stmikroyal.ac.id/index.php/jurdimas

rumah tangga untuk dapat membantu perekonomian keluarga serta menghasilkan peluang usaha dan mengatasi kebosanan.

\section{Motivasi}

Motivasi berasal dari bahasa Latin "movere", yang berarti menggerakkan. Menurut Weiner (1990) yang dikutip Elliot et.al (2000), motivasi didefenisikan sebagai kondisi internal yang membangkitkan kita untuk bertindak, mendorong kita mencapai tujuan tertentu, dan membuat kita tetap tertarik dalam kegiatan tertentu. Menurut Uno (2007), motivasi dapat diartikan sebagai dorongan internal dan eksternal dalam diri seseorang yang diindikasikan dengan adanya hasrat dan minat, dorongan dan kebutuhan, harapan dan cita-cita, penghargaan, dan penghormatan. Sedangkan Imron (1966) menjelaskan bahwa motivasi berasal dari bahasa Inggris "motivation" yang berarti dorongan atau pengalasan untuk melakukan suatu aktivitas hingga mencapai tujuan. Jadi dapat dikatakan motivasi adalah sesuatu alasan yang mendorong seseorang untuk melakukan atau menyelesaikan atau menghentikan satu aktivitas guna mencapai tujuan tertentu yang diinginkan.

Untuk dapat memulai kegiatan wirausaha dari rumah maka tidak terlepas dari adanya dorongan untuk memicu para ibu rumah tangga mengambil sikap dan keputusan untuk bertindak. Tentu tidaklah mudah bagi seorang ibu rumah tangga untuk mengambil keputusan berwirausaha. Dibutuhkan motivasi yang sangat kuat untuk mendorong ibu rumah tangga untuk mau berkecimpung memulai kegiatan wirausaha.

Seringkali di awal sudah muncuk ketakutan akan merugi, risiko kegagalan yang mungkin terjadi. Maka motivasi merupakan kunci utama yang akan mampu mendorong manusia untuk bertindak. Biasanya motivasi awal yang muincul pada diri seorang ibu rumah tangga untuk berwirausaha adalah karena alasan keuangan keluarga. Selain itu ada juga motivasi lain yaitu memiliki hobby tertentu sehingga produk yang muncul dari kegiatan menyalurkan hobby yang dapat dipasarkan. Motivasi lainnya adalah keinginan untuk memiliki karir sendiri dan untuk berprestasi. Apapun berbagai alasan yang ada, tetaplah dibutuhkan motivasi yang kuat bagi seorang ibu rumahtangga sehingga mengambil keputusan untuk berwirausaha.

Adapun faktor-faktor yang mempengaruhi motivasi usaha adalah kondisi lingkungan seperti sistem hukum, industri, pasar modal dan kondisi ekonomi nasional mempengaruhi wirausaha, tetapi motivasi wirausahawan akan mengarahkan tindakan wirausaha pada kondisi lingkungan yang berbeda.

Dengan adanya motivasi yang berasal dari dalam diri kita, kita akan dengan mudah menjalankan apapun karena motivasi merupakan modal awal yang harus dipunyai dan dikembangkan oleh seorang wirausahawan. Tanpa adanya motivasi mustahil suatu usaha dapat berjalan sediri tanpa ada yang menggerakkannya.

Tujuan Kegiatan

- Menambah pengetahuan ibu rumah tangga dalam hal motivasi dan kewirausahaan.

- Menggerakkan para kaum ibu rumah tangga di Kelurahan Sendang Sari, Kec Kisaran Barat untuk berwirausaha mengerjakan sesuatu yang kreatif dan memiliki peluang usaha.

- Pada akhirnya pengetahuan ini dapat membantu para ibu rumah tangga dalam usaha peningkatan pendapatan 
Available online at https://jurnal.stmikroyal.ac.id/index.php/jurdimas

rumah tangga melalui keberanian untuk berwirausaha dari rumah.

Manfaat kegiatan pengabdian tentang motivasi dan kewirausahaan ini, diharapkan para ibu rumah tangga mampu mengetahui, memahami, membuat dan menerapkan pengetahuan dalam hal motivasi dan kewirausahaan dan mampu mengimplementasikannya dalam berwirausaha mengerjakan sesuatu yang kreatif serta memiliki peluang usaha untuk membantu usaha peningkatan pendapatan rumah tangga.

Peserta dari kegiatan ini terdiri dari ibu rumah tangga di Kelurahan Sendang Sari, Kec Kisaran Barat dengan jumlah peserta 20 orang.

\section{METODE}

Kegiatan pelatihan yang diselenggarakan dilakukan dalam tiga tahapan sebagai berikut:

\section{Tahap Persiapan}

Pada tahap ini dilakukan kegiatan pertemuan dengan pihak Kelurahan Sendang Sari, Kecamatan Kisaran Barat, menjelaskan tentang adanya pemberian pelatihan pengetahuan kepada warga Kelurahan khususnya Ibu Rumah Tangga terkait dengan visi misi tim dalam pelaksanaan Tri Dharma Perguruan Tinggi, berkoordinasi dengan pihak kelurahan mengenai sasaran peserta, syarat peserta, jumlah peserta, tempat Pembagian tugas kepada anggota tim, penyusunan materi dan persiapan pendukung lainnya.

\section{Tahap Pelaksanaan}

Pelaksanaan pelatihan ditujukan kepada 20 orang peserta yang memenuhi kriteria yaitu ibu rumah tangga yang tidak bekerja di Kelurahan Sendang Sari.
Kegiatan ini dilakukan dengan melakukan tatap muka interaktif dengan peserta, menggunakan media pembelajaran video untuk menggugah pemikiran para ibu rumah tangga melalui audio visual.

\section{Tahap Evaluasi}

Pada tahap evaluasi dilakukan penilaian keberhasilan peserta menangkap pembelajaran yang telah diberikan mengenai motivasi dan kewirausahaan.

Para peserta diberikan kuesioner mengenai motivasi dan kewirausahaan untuk melihat sejauh mana pemahaman para ibu rumah tangga terhadap materi yang telah disampaikan.

Kuesioner yang diberikan berisikan pertanyaan-pertanyaan tertutup.

\section{PEMBAHASAN}

Dari hasil pelatihan, kegiatan tersebut telah direalisasikan sesuai dengan rencana dan berjalan dengan lancar dan efektif.

Dari hasil pengolahan data kuesioner seluruh peserta memberikan respon yang positif (100\% menjawab ya untuk seluruh butir pertanyaan). Dari hasil ini maka diyakini peserta mendapatkan pengetahuan, pemahaman tentang apa itu wirausaha, motivasi untuk berwirausaha, perkembangan ekonomi kreatif dan penguatan dorongan bagi para ibu untuk mengambil keputusan melakukan wirausaha pada bidang industri kreatif. Sehingga bisa dikatakan bahwa terjadi peningkatan kemampuan para ibu rumah tangga menjadi lebih baik dibandingkan dari sebelum pelatihan yang dilakukan. Para peserta pelatihan memiliki kemampuan dasar tentang pemahaman akan industri kreatif dan melakukan kegiatan wirausaha yang produktif tanpa 
Jurdimas (Jurnal Pengabdian Kepada Masyarakat) Royal

Vol. 2 No. 1, Jan 2019, hlm. 43 - 48

DOI: https://doi.org/10.33330/jurdimas.v2i1.319

ISSN 2614-7912 (Print)

ISSN 2622-3813 (Online)

Available online at https://jurnal.stmikroyal.ac.id/index.php/jurdimas

perlu meninggalkan rumah.

\section{SIMPULAN}

Kesimpulan dari kegiatan pengabdian masyarakat ini adalah:

1. Pelaksanaan kegiatan pelatihan motivasi dan kewirausahaan ini dapat berlangsung dan selesai dengan baik.

2. Para peserta pelatihan mampu mengetahui ketrampilan berbasis industri kreatif apa saja yang dapat dilakukan untuk membantu perekonomian rumah tangga.

3. Para peserta pelatihan dapat membuat ketrampilan berbasis industri kreatif untuk membantu perekonomian rumah tangga.

4. Motivasi berperan penting dalam mendorong ibu rumah tangga dalam membuat industri kreatif untuk membantu perekonomian rumah tangga.

\section{DAFTAR PUSTAKA}

Ali Imron. 1996. Belajar dan Pembelajaran. Jakarta: Pustaka Jaya

B. Uno, Hamzah. 2008. Teori Motivasi dan Pengukurannya, Jakarta : Bumi Aksara.

Bygrave, William D. 1997. The Portable MBA in Entrepreneurship. John Willey \& Son, Inc @ nd, New York.

Elliot et al. 2000. Educational Psychology: Efective Teaching, Effective Learning, 3rd edition. United States of America: Mc Graw Hill Companies.

Entrepreneur Company. 2013. Motivasi Kewirausahaan. Diakses dari: http://entrecompany.blogspot.com/2 013/05/motivasi- kewirausahaan.html pada tanggal 20 Juni 2018

Episentrum. 2009. Kreativitas Wirausaha. Diakses dari: http://episentrum.com/artikelpsikologi/kreativitaswirausaha/\#mor e-515 pada tanggal 20 Juni 2018.

Justelsa. 2010. Teori Motivasi. Diakses dari: http://www.justelsa.com/2010/05/te ori-motivasi-david-cmcclelland.html pada tanggal 20 Juni 2018.

Zakky. 2018. Pengertian Wirausaha secara umum dan menurut para ahli. Diakses dari: https://www.zonareferensi.com/pen gertian-wirausaha/ pada 11 Februari 2019 